\title{
The assessment of changes in the level of technical infrastructure development for former regional centres - a comparative analysis
}

\author{
Agata Pawłat-Zawrzykraj ${ }^{1 . *}$, Konrad Podawca $^{1}$ \\ ${ }^{1}$ Warsaw University of Life Sciences -SGGW, Faculty of Civil and Environmental Engineering, \\ Department of Civil Engineering, Nowoursynowska 159, 02-776 Warsaw, Poland
}

\begin{abstract}
The article presents the assessment of urban development measured mainly by the service level and dynamics of changes in the field of technical infrastructure. This kind of analysis can give some long-term overview of social, economic and spatial phenomena. The objects of the research were 28 cities - former regional centers that lost their status due to administrative reform in 1999. The changing of the administrative significance of these cities was assumed to be an important external factor that might adversely affect their development. A multi-indicator analysis concerning the infrastructure issues was worked out for the years 20012016 on the basis of statistical data of the Central Statistical Office, available in Local Data Bank (LDB). The obtained results for individual indicators enabled rating the technical infrastructure development of the studied cities. Furthermore, diversity and spatial distribution of the urban units with high, medium and low rates of technical infrastructure development were presented.
\end{abstract}

\section{Introduction}

The administrative reform carried out in 1999 changed the status of many Polish cities. 28 of the 49 large and medium-sized cities lost their rank as regional capitals. Changes of an administrative nature have become one of the external causes of socio-economic changes in many urban centres. Factors affecting the development of Polish cities were divided into various groups (e.g. small, medium, large) and became the subject of strategic and operational studies, as well as scientific publications. Recent research on these cities, including former regional capitals, are presented in works of several authors such as Chleba [1-2], Runge [3], Szymańska [4], Komorowski [5], Kurniewicz and Swianiewicz [6], Kisiała [7] and Dembicka-Niemiec [8]. The abovementioned publications mostly consider the current diversity of cities in terms of social and economic conditions. The analyses conducted by Dembicka-Niemiec [8] assessed the diversity of the cities in terms of the level of sustainable development, and also taking into account, apart from the already mentioned factors, environmental and infrastructural criteria. The studies mostly confirm the common opinion that former regional capitals are much less developed than the cities

\footnotetext{
*Corresponding author: agata_pawlat_zawrzykraj@sggw.p1
} 
that preserved their status of the capital after the administrative government reform of 1999 [7].

The aim of the study is a comparative analysis of changes that have occurred in former regional capitals within the scope of technical infrastructure. The level of service regarding water and sewage system, and natural gas network determines not only the quality of life but also affects the state of the environment. The infrastructural development, especially of the sewage system and liquid gas network, indirectly reflect the economic situation of the analysed cities [8] and can be used for a broader range of analyses and forecasts for the presented cities.

\section{The study object}

The survey covered 28 cities, which before 1999 had a regional status and functioned as the seat for state authorities. After the administrative reform in 1999 the cities were demoted to become capitals of counties (poviats) and bases of local government authorities. The cities are a diverse group of administrative units. In terms of area, they can be divided into three main groups: small, medium and large cities. The medium ones with an area of more than $50 \mathrm{~km}^{2}$ and less than $100 \mathrm{~km}^{2}$ predominate. In terms of the population, the largest group of the cities are the ones with a population of 50-100 thousand residents (data for 2016, BDL). It should be also pointed out that there are three cites with a population below 50 thousand, and two cities with a population of more than 200 thousand. Almost all the cities (except Leszno, Suwałki and Siedlce) are of the demographic regression type which means that they are experiencing a decline in their population (Table 1).

Table 1. Selected characteristics describing the analyzed cities.

\begin{tabular}{|c|c|c|c|}
\hline \multicolumn{2}{|c|}{ Characteristics } & $\begin{array}{c}\text { No. } \\
\text { of cities }\end{array}$ & City \\
\hline \multirow{3}{*}{$\begin{array}{l}\text { The city's } \\
\text { area } \\
{\left[\mathrm{km}^{2}\right]}\end{array}$} & $\leq 50$ & 11 & $\begin{array}{l}\text { Ostrołęka, Zamość, Siedlce, Leszno, Łomża, Słupsk, Krosno, Przemyśl, } \\
\text { Biała Podlaska }\end{array}$ \\
\hline & $\begin{array}{l}(50- \\
100)\end{array}$ & 13 & $\begin{array}{l}\text { Legnica, Nowy Sącz, Suwałki, Piotrków Trybunalski, Kalisz, Tarnów, } \\
\text { Elbląg, Konin, Włocławek, Wałbrzych, Tarnobrzeg, Płock, Koszalin }\end{array}$ \\
\hline & $\geq 100$ & 4 & Jelenia Góra, Radom, Bielsko-Biała, Częstochowa \\
\hline \multirow{4}{*}{$\begin{array}{l}\text { Population } \\
\text { in } 2016 \\
\text { [thousands] }\end{array}$} & $\leq 50$ & 3 & Krosno (-1867), Tanobrzeg (-2727), Skierniewice (-147) \\
\hline & $\begin{array}{c}(50- \\
100>\end{array}$ & 14 & $\begin{array}{l}\text { Ostrołęka }(-1819)^{1)} \text {, Biała Podlaska (-965), Przemyśl (-6014), Łomża } \\
(-1156) \text {, Chełm }(-5282) \text {, Leszno }(+602) \text {, Zamość }(-2518) \text {, Suwałki }(+775) \text {, } \\
\text { Piotrków Trybunalski }(-6483) \text {, Konin }(-7158) \text {, Siedlce }(+413) \text {, Jelenia Góra } \\
(-9036) \text {, Nowy Sącz }(-460) \text {, Słupsk }(-8101)\end{array}$ \\
\hline & $\begin{array}{l}(100- \\
200)\end{array}$ & 9 & $\begin{array}{l}\text { Legnica (-6485), Kalisz (-7431), Koszalin (-902), Tarnów (-9975), } \\
\text { Włocławek (-8887), Wałbrzych (-16100), Elbląg (-7035), Płock (-7064), } \\
\text { Bielsko Biała (-6283) }\end{array}$ \\
\hline & $\geq 200$ & 2 & Radom (-14967), Częstochowa (-25707) \\
\hline
\end{tabular}

\section{Methods}

The research is based on a multidimensional comparative analysis, leveraging the indicators concerning the water supply system, sewage system and natural gas distribution network. The following study stages have been completed:

- filtering of data collected from the Local Data Bank [9] for the years 2001-2016, covering the fields of population, housing and public utilities; the period covered by the analysis is due to the lack of complete data for the years 1999-2000;

- designation of indicators for the selected features to achieve their comparability;

- normalization of indicators to determine their significance in the city's development; 
- designation of synthetic indicators and the determination of limiting values.

In the study, a typical set of indicators was implemented. The assessment of the level of social and spatial development of technical infrastructure in the studied cities was made using the following indicators:

- development of the length of the water supply system, sewage system and natural gas distribution network in relation to population density, expressed by the formula (1):

$$
X_{1(3)(5)}=\left[\frac{L_{w(s)(g) 16}}{N_{R 16} / A_{C 16}}-\frac{L_{w(s)(g) 01}}{N_{R 01} / A_{C 01}}\right]
$$

where:

$L_{w(s)(g) 01(16)}$ - the length of water supply system (s - sewage system, g - natural gas distribution network) in 2001 and 2016 , [km];

$A_{C 01(16)}$ - the city's area in 2001 and $2016,\left[\mathrm{~km}^{2}\right]$;

$N_{R 01(16)}$ - number of residents per permanent address as of 31 December 2001 and 31 December 2016 [-];

- development of water, sewage and natural gas connections in relation to the city's area, calculated by the formula (2):

$$
X_{2(4)(6)}=\left[\frac{N_{C w(s)(g) 16}}{A_{C 16}}-\frac{N_{C w(s)(g) 01}}{A_{C 01}}\right]
$$

where:

$\mathrm{N}_{\mathrm{Cw}(\mathrm{s})(\mathrm{g})}$ 01(16) - number of water supply connections (s- sewage connections, $\mathrm{g}$ - gas connections) in relation to number of dwellings and communal housing buildings in 2001 and 2016, [-];

$\mathrm{A}_{\mathrm{C} 01(16)}$ - the city's area in 2001 and 2016, $\left[\mathrm{km}^{2}\right]$;

The next stage of the work on the indicators was their normalization, which allowed converting the values of indicators expressed in different units into a comparable form. Due to the fact that all indicators have a stimulant status, Perkal's formula [10] has been applied (3):

$$
Z_{i j}=\frac{x_{i j}-x_{m}}{s_{j}}
$$

where:

$Z_{i j}$ - normalized value of $\mathrm{j}$-indicators for $\mathrm{i}-\mathrm{object}$;

$X_{i j}$ - value of $\mathrm{j}$-characteristic for $\mathrm{i}$-city;

$X_{m}$ - the arithmetic mean of the calculated value of $\mathrm{j}$-indicator;

$S_{j}$ - the standard deviation of the value of $\mathrm{j}$-indicator;

Aggregated data concerning technical infrastructure development in the analysed cities were compiled with Perkal's synthetic indicator according to the following formula [4]:

$$
W_{D T I}=\frac{1}{n} \sum_{j=1}^{n} Z_{i j}
$$


where:

$W_{D T I}$ - the synthetic indicator for spatial development of technical infrastructure, $\mathrm{j}-1,2, . ., \mathrm{n}$; $Z_{i j}$ - the normalized value of $\mathrm{x}_{\mathrm{ij}}$;

$\mathrm{n}$ - number of the considered indicators;

The higher the value of the synthetic indicator means the more favourable socio-spatial development of the technical infrastructure in the analyzed cities in the years 2001-2016. Values closer to 0 indicate an average e situation, whereas negative values reflect an inadequate level of the infrastructure development. On the basis of the range of synthetic

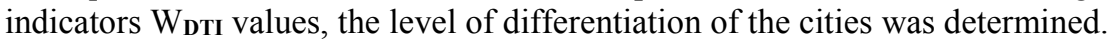

\section{Results}

The values of the calculated indicators and their normalized values are presented in Table 2 and Table 3. According to the method employed in the study, the obtained normalised values $\left(Z_{1}-Z_{6}\right)$ for each analyzed infrastructure system enabled indicating four groups of cities corresponding to the various pace of their infrastructure development.

- group A -the normalized value of the indicator is above 1,

- group B -the normalized value of the indicator is above 0 and below 1 ,

- group $\mathrm{C}-$ the normalized value of the indicator is between -1 and 0 ,

- group D -the normalized value of the indicator is below - 1,

According to the above-stated principles, every studied city has been assigned to the appropriate group (Table 4).

Table 2. The indicators describing the development of the water supply system, sewage system and natural gas distribution network in the analyzed cities.

\begin{tabular}{|c|c|c|c|c|c|c|c|}
\hline No & City & $\mathbf{X}_{1}$ & $\mathbf{X}_{2}$ & $\mathbf{X}_{3}$ & $\mathbf{X}_{4}$ & $\mathbf{X}_{5}$ & $\mathbf{X}_{6}$ \\
\hline 1 & Jelenia Góra & 0.0238394 & 0.0476384 & 0.0594389 & 0.1657386 & 0.0260353 & 0.1726381 \\
\hline 2 & Legnica & 0.2106531 & 0.1659480 & 0.1900175 & 0.3091103 & 0.0798415 & 0.0935617 \\
\hline 3 & Wałbrzych & 0.0230002 & 0.1652158 & 0.0227253 & 0.0419257 & 0.0157097 & 0.3398472 \\
\hline 4 & Włocławek & 0.0262978 & 0.1336832 & 0.0829426 & 0.5954866 & 0.0221461 & 0.1455818 \\
\hline 5 & Biała Podlaska & 0.0606296 & 0.6098683 & 0.0592661 & 0.6523656 & 0.0207410 & 0.1565879 \\
\hline 6 & Chełm & 0.0231541 & 0.0815516 & 0.0397278 & 0.1685995 & 0.0311503 & 0.5429382 \\
\hline 7 & Zamość & 0.0170960 & 0.4111788 & 0.0140225 & 0.4762010 & 0.0265183 & 0.4871437 \\
\hline 8 & Piotrków Tryb & 0.0409278 & 0.1751381 & 0.0519390 & 0.2570862 & 0.0270845 & 0.3408260 \\
\hline 9 & Skierniewice & 0.0205837 & 0.3978203 & 0.0441122 & 0.6300768 & 0.0251648 & 0.4592401 \\
\hline 10 & Nowy Sącz & 0.0950734 & 0.7348663 & 0.1340991 & 1.3328502 & 0.0764249 & 0.5925169 \\
\hline 11 & Tarnów & 0.0459120 & 0.2412269 & 0.1076190 & 0.3101686 & 0.0451031 & 0.3162476 \\
\hline 12 & Ostrołęka & 0.0251532 & 0.7861557 & 0.0324589 & 0.8881629 & 0.0077636 & 0.3587453 \\
\hline 13 & Płock & 0.0673014 & 0.2269146 & 0.0687421 & 0.1244653 & 0.0323626 & 0.1524134 \\
\hline 14 & Radom & 0.0715394 & 0.3424623 & 0.1296064 & 0.5982703 & 0.0813884 & 0.3530576 \\
\hline 15 & Siedlce & 0.0209287 & 0.3068437 & 0.0242365 & 0.2580270 & 0.0072133 & 0.4608330 \\
\hline 16 & Krosno & 0.0735147 & 0.4036933 & 0.0690261 & 0.9351776 & 0.0453415 & 0.1930963 \\
\hline 17 & Przemyśl & 0.0254492 & 0.0339444 & 0.0603735 & 0.3367675 & 0.0259378 & 0.2276248 \\
\hline 18 & Tarnobrzeg & 0.0927415 & 0.0813692 & 0.2211860 & 0.2492703 & 0.0602546 & 0.1060959 \\
\hline 19 & Łomża & 0.0133089 & 0.2704810 & 0.0165296 & 0.7078926 & 0.0296870 & 0.5247029 \\
\hline 20 & Suwałki & 0.0441712 & 0.1969698 & 0.0514146 & 0.2518057 & 0.0277870 & 0.0234404 \\
\hline 21 & Shupsk & 0.0203985 & 0.2308227 & 0.0147742 & 0.2366165 & 0.0219365 & 0.3863268 \\
\hline 22 & Bielsko-Biała & 0.1920230 & 0.5258174 & 0.3806602 & 0.7406829 & 0.0498445 & 0.2915744 \\
\hline 23 & Częstochowa & 0.1004025 & 0.1200136 & 0.1618442 & 0.4841933 & 0.1097372 & 0.2297501 \\
\hline 24 & Elbląg & 0.0241073 & 0.0421318 & 0.0277282 & 0.0044709 & 0.0266625 & 0.0213992 \\
\hline 25 & Kalisz & 0.0279891 & 0.2620745 & 0.0827650 & 0.4513093 & 0.0240331 & 0.3437198 \\
\hline 26 & Konin & 0.0440842 & 0.1842368 & 0.0634656 & 0.3089364 & 0.0381180 & 0.1323801 \\
\hline 27 & Leszno & 0.0110708 & 0.8756049 & 0.0396737 & 0.9876930 & 0.0245409 & 0.5704436 \\
\hline 28 & Koszalin & 0.0794844 & 0.1069220 & 0.0889662 & 0.0861242 & 0.0772357 & 0.1859905 \\
\hline
\end{tabular}


Explanations: $\mathrm{X}_{1}$ - the length of water supply system ( $\mathrm{X}_{3}$ - sewage system, $\mathrm{X}_{5}$ - gas distribution network) in relation to population density; $X_{2}$ - development of water $\left(\mathrm{X}_{4}-\right.$ sewage, $\mathrm{X}_{6}-$ gas $)$ in relation to the city's area.

Table 3. The normalized values of the indicators for the development of the water and sewage systems and natural gas network and Perkal's synthetic indicator.

\begin{tabular}{|c|c|c|c|c|c|c|c|c|}
\hline No & City & $\mathrm{Z}_{1}$ & $\mathbf{Z}_{2}$ & $\mathbf{Z}_{3}$ & $\mathbf{Z}_{4}$ & $\mathbf{Z}_{5}$ & $\mathrm{Z}_{6}$ & $\mathbf{W}_{\text {DTI }}$ \\
\hline 1 & Jelenia Góra & -0.61676 & -1.06250 & -0.30661 & -0.88155 & -0.50564 & -0.72231 & -0.68256 \\
\hline 2 & Legnica & 3.16386 & -0.54692 & 1.35400 & -0.43634 & 1.62954 & -1.19620 & 0.66132 \\
\hline 3 & Wałbrzych & -0.63374 & -0.55011 & -0.77351 & -1.26602 & -0.91539 & 0.27973 & -0.64317 \\
\hline 4 & Włocławek & -0.56701 & -0.68752 & -0.00771 & 0.45295 & -0.65997 & -0.88446 & -0.39229 \\
\hline 5 & Biała Podlaska & 0.12778 & 1.38762 & -0.30881 & 0.62957 & -0.71573 & -0.81850 & 0.05032 \\
\hline 6 & Chełm & -0.63063 & -0.91471 & -0.55728 & -0.87266 & -0.30266 & 1.49682 & -0.29685 \\
\hline 7 & Zamość & -0.75323 & 0.52176 & -0.88419 & 0.08253 & -0.48647 & 1.16245 & -0.05952 \\
\hline 8 & Piotrków Tryb. & -0.27093 & -0.50687 & -0.40199 & -0.59789 & -0.46400 & 0.28560 & -0.32601 \\
\hline 9 & Skierniewice & -0.68264 & 0.46355 & -0.50153 & 0.56036 & -0.54018 & 0.99523 & 0.04913 \\
\hline 10 & Nowy Sącz & 0.82483 & 1.93235 & 0.64287 & 2.74268 & 1.49396 & 1.79393 & 1.57177 \\
\hline 11 & Tarnów & -0.17007 & -0.21886 & 0.30611 & -0.43305 & 0.25103 & 0.13831 & -0.02109 \\
\hline 12 & Ostrołęka & -0.59017 & 2.15586 & -0.64972 & 1.36179 & -1.23071 & 0.39299 & 0.24001 \\
\hline 13 & Płock & 0.26280 & -0.28124 & -0.18830 & -1.00971 & -0.25455 & -0.84352 & -0.38575 \\
\hline 14 & Radom & 0.34856 & 0.22231 & 0.58573 & 0.46159 & 1.69093 & 0.35890 & 0.61134 \\
\hline 15 & Siedlce & -0.67566 & 0.06708 & -0.75429 & -0.59497 & -1.25255 & 1.00478 & -0.36760 \\
\hline 16 & Krosno & 0.38854 & 0.48914 & -0.18469 & 1.50779 & 0.26049 & -0.59971 & 0.31026 \\
\hline 17 & Przemyśl & -0.58418 & -1.12217 & -0.29473 & -0.35045 & -0.50951 & -0.39279 & -0.54230 \\
\hline 18 & Tarnobrzeg & 0.77764 & -0.91550 & 1.75038 & -0.62216 & 0.85228 & -1.12109 & 0.12026 \\
\hline 19 & Łomża & -0.82987 & -0.09138 & -0.85230 & 0.80200 & -0.36073 & 1.38754 & 0.00921 \\
\hline 20 & Suwałki & -0.20530 & -0.41173 & -0.40866 & -0.61428 & -0.43612 & -1.61642 & -0.61542 \\
\hline 21 & Shupsk & -0.68639 & -0.26420 & -0.87463 & -0.66145 & -0.66829 & 0.55828 & -0.43278 \\
\hline 22 & Bielsko-Biała & 2.78684 & 1.02134 & 3.77847 & 0.90382 & 0.43918 & -0.00955 & 1.48668 \\
\hline 23 & Częstochowa & 0.93268 & -0.74709 & 0.99571 & 0.10735 & 2.81589 & -0.38005 & 0.62075 \\
\hline 24 & Elbląg & -0.61134 & -1.08649 & -0.70989 & -1.38233 & -0.48075 & -1.62866 & -0.98324 \\
\hline 25 & Kalisz & -0.53278 & -0.12801 & -0.00997 & 0.00523 & -0.58509 & 0.30294 & -0.15795 \\
\hline 26 & Konin & -0.20705 & -0.46722 & -0.25540 & -0.43688 & -0.02616 & -0.96357 & -0.39271 \\
\hline 27 & Leszno & -0.87516 & 2.54567 & -0.55797 & 1.67086 & -0.56494 & 1.66165 & 0.64668 \\
\hline 28 & Koszalin & 0.50935 & -0.80415 & 0.06890 & -1.12877 & 1.52614 & -0.64230 & -0.07847 \\
\hline
\end{tabular}

Explanations: $Z_{1}-Z_{6}$ - normalized values, $\mathrm{W}_{\mathrm{DTI}}$ - Perkal's synthetic indicator

Table 4. Table summarizing groups of cities according to the individual normalized indicators.

\begin{tabular}{|c|c|c|c|c|c|c|c|c|}
\hline \multirow{2}{*}{$\begin{array}{c}\text { Indica } \\
\text {-tor }\end{array}$} & \multicolumn{8}{|c|}{ Groups (A, B, C, D) and number (N) of cities assigned to each group (per group) } \\
\hline & $\mathbf{A}$ & $\mathbf{N}$ & B & $\mathbf{N}$ & $\mathbf{C}$ & $\mathbf{N}$ & D & $\mathbf{N}$ \\
\hline 1. & 2. & 3. & 4. & 5. & 6. & 7. & 8. & 9. \\
\hline $\mathrm{Z}_{1}$ & $\begin{array}{l}\text { Bielsko-Biała, } \\
\text { Jelenia Góra }\end{array}$ & 2 & $\begin{array}{l}\text { Biała Podlaska, } \\
\text { Płock, Radom, } \\
\text { Krosno, Koszalin, } \\
\text { Tarnobrzeg, Nowy } \\
\text { Sącz, Częstochowa }\end{array}$ & 8 & $\begin{array}{l}\text { Leszno, Łomża, Zamość, Słupsk, } \\
\text { Skierniewice, Siedlce, Legnica, } \\
\text { Chełm, Wałbrzych, Elbląg, } \\
\text { Ostrołęka, Przemyśl, Włocławek, } \\
\text { Kalisz, Piotrków Trybunalski, } \\
\text { Konin, Suwałki, Tarnów }\end{array}$ & 18 & - & 0 \\
\hline $\mathrm{Z}_{2}$ & $\begin{array}{l}\text { Bielsko-Biała, } \\
\text { Biała Podlaska, } \\
\text { Nowy Sącz, } \\
\text { Ostrołęka, } \\
\text { Leszno }\end{array}$ & 5 & $\begin{array}{l}\text { Siedlce, Radom, } \\
\text { Skierniewice, } \\
\text { Krosno, Zamość }\end{array}$ & 5 & $\begin{array}{l}\text { Tarnobrzeg, Chełm, Koszalin, } \\
\text { Częstochowa, Włocławek, Płock } \\
\text { Legnica, Jelenia Góra, Piotrków } \\
\text { Trybunalski, Konin, Suwałki, } \\
\text { Słupsk, Tarnów, Kalisz, Łomża }\end{array}$ & 15 & $\begin{array}{l}\text { Przemyśl, } \\
\text { Elbląg, } \\
\text { Wałbrzych }\end{array}$ & 3 \\
\hline$Z_{3}$ & $\begin{array}{l}\text { Jelenia Góra, } \\
\text { Tarnobrzeg, } \\
\text { Bielsko-Biała }\end{array}$ & 3 & $\begin{array}{l}\text { Koszalin, Tarnów, } \\
\text { Radom, Nowy Sącz, } \\
\text { Częstochowa }\end{array}$ & 5 & $\begin{array}{l}\text { Zamość, Słupsk, Łomża, Legni- } \\
\text { ca, Siedlce, Elbląg, Ostrołęka, } \\
\text { Leszno, Chełm, Skierniewice, } \\
\text { Suwałki, Piortków Trybunalski, } \\
\text { Biała Podlaska, Wałbrzych, } \\
\text { Przemyśl, Konin, Płock, Krosno, } \\
\text { Kalisz, Włocławek }\end{array}$ & 20 & - & 0 \\
\hline
\end{tabular}


Table 4. Continued.

\begin{tabular}{|c|c|c|c|c|c|c|c|c|}
\hline 1. & 2. & 3. & 4. & 5. & 6. & 7. & 8. & 9. \\
\hline$Z_{4}$ & $\begin{array}{l}\text { Ostrołęka, } \\
\text { Krosno, } \\
\text { Leszno, Nowy } \\
\text { Sącz }\end{array}$ & 4 & $\begin{array}{l}\text { Kalisz, Zamość, } \\
\text { Częstochowa, } \\
\text { Włocławek, Radom, } \\
\text { Skierniwice, Biała } \\
\text { Podlaska, Łomża, } \\
\text { Bielsko-Biała }\end{array}$ & 9 & $\begin{array}{l}\text { Wałbrzych, Chełm, Słupsk, } \\
\text { Tarnobrzeg, Suwałki, Piotrków } \\
\text { Trybunalski, Siedlce, Konin, } \\
\text { Jelenia Góra, Tarnów, Przemyśl }\end{array}$ & 11 & $\begin{array}{l}\text { Elbląg, } \\
\text { Legnica, } \\
\text { Koszalin, } \\
\text { Płock }\end{array}$ & 4 \\
\hline$Z_{5}$ & $\begin{array}{l}\text { Nowy Sącz, } \\
\text { Koszalin, } \\
\text { Jelenia Góra, } \\
\text { Radom, } \\
\text { Częstochowa }\end{array}$ & 5 & $\begin{array}{l}\text { Tarnów, Krosno, } \\
\text { Bielsko-Biała, } \\
\text { Tarnobrzeg }\end{array}$ & 4 & $\begin{array}{l}\text { Legnica, Biała Podlaska, Słupsk, } \\
\text { Włocławek, Kalisz, Leszno, } \\
\text { Skierniewice, Przemyśl, } \\
\text { Wałbrzych, Zamość, Elbląg, } \\
\text { Piotrków Trybunalski, Suwłki, } \\
\text { Lomża, Chełm, Płock, Konin }\end{array}$ & 17 & $\begin{array}{l}\text { Siedlce, } \\
\text { Ostrołęka }\end{array}$ & 2 \\
\hline$Z_{6}$ & $\begin{array}{l}\text { Siedlce, } \\
\text { Zamość, } \\
\text { Łomża, Chełm, } \\
\text { Leszno, Nowy } \\
\text { Sącz }\end{array}$ & 6 & $\begin{array}{l}\text { Tarnów, Legnica, } \\
\text { Piotrków } \\
\text { Trybunalski, Kalisz, } \\
\text { Radom, Ostrołęka, } \\
\text { Słupsk, } \\
\text { Skierniewice }\end{array}$ & 8 & $\begin{array}{l}\text { Konin, Włocławek, Płock, Biała } \\
\text { Podlaska, Wałbrzych, Koszalin, } \\
\text { Krosno, Przemyśl, Częstochowa, } \\
\text { Bielsko-Biała }\end{array}$ & 10 & $\begin{array}{l}\text { Elbląg, } \\
\text { Suwałki, } \\
\text { Jelenia Góra, } \\
\text { Tarnobrzeg }\end{array}$ & 4 \\
\hline
\end{tabular}

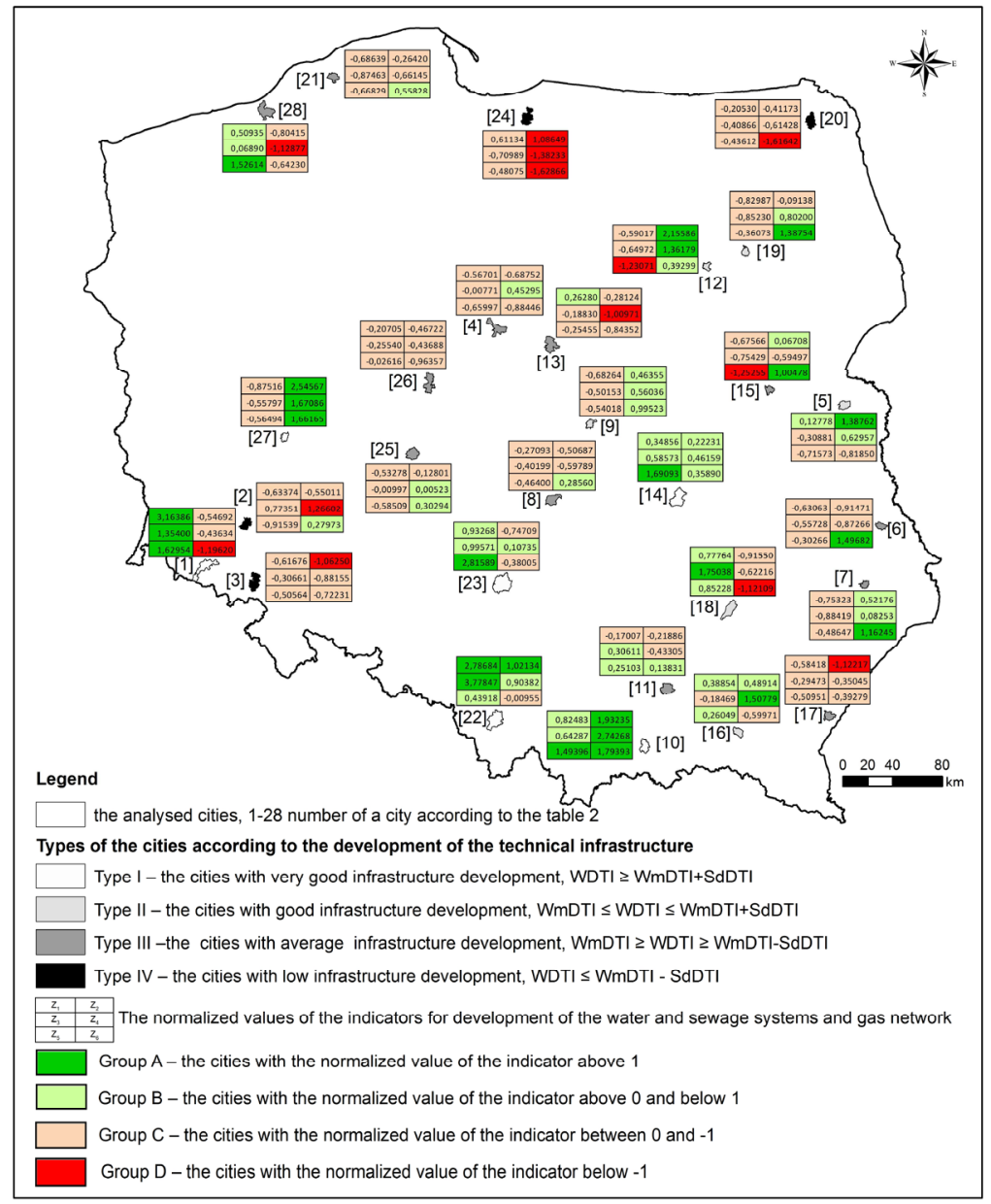

Fig. 1. Spatial distribution of the various types of technical infrastructure development. 


\section{Conclusions}

The state of technical infrastructure development in the years 2001 - 2016 was satisfactory in the case of 5 cities assigned to Type I (Nowy Sącz, Bielsko-Biała, Jelenia Góra, Leszno, Częstochowę i Radom) and 7 cities of Type II (Krosno, Ostrołęka, Tarnobrzeg, Biała Podlaska, Skierniewice i Łomża). The largest group of the cities are those with an average level of technical infrastructure development (Tarnów, Zamość, Koszalin, Kalisz, Chełm, Piotrków Trybunalski, Siedlce, Płock, Włocławek, Konin, Słupsk i Przemyśl). The worst situation was observed in the following four cities: Suwałki, Legnica, Wałbrzych and Elbląg (Fig. 2). There is no apparent correlation between the spatial distribution and the typological classification of the cities. The cities with a low level of infrastructure development (Type IV) are located in the southeast, north and northwest parts of Poland which can be classified as socio-economic problem areas [11].

\begin{tabular}{|c|c|c|}
\hline Elbląg & -0.98324 & \multirow{16}{*}{$\begin{array}{l}\text { Nowy Sącz } \\
\text { Bielsko-Biała } \\
\text { Jelenia Góra }\end{array}$} \\
\hline Wałbrzych & -0.68256 & \\
\hline Legnica & 0.66132 & \\
\hline Suwałki & 0.64668 & \\
\hline Przemyśl & 0.62075 & \\
\hline Słupsk & \begin{tabular}{c|c}
-0.43278 & 0.61134 \\
\end{tabular} & \\
\hline Konin & \begin{tabular}{l|l}
-0.39271 & 0.31026 \\
\end{tabular} & \\
\hline Włocławek & \begin{tabular}{l|l}
-0.39229 & 0.24001 \\
\end{tabular} & \\
\hline Płock & 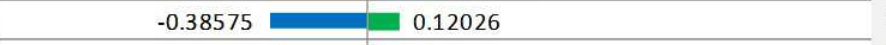 & \\
\hline Siedlce & -0.36760 & \\
\hline Piotrków Trybunalski & $-0.32601 \square 0.04913$ & \\
\hline Chełm & $-0.29685 \square 0.00921$ & \\
\hline Kalisz & -0.15795 & \\
\hline Koszalin & $-0.07847=$ & \\
\hline Zamość & -0.05952 & \\
\hline Tarnów & -0.02109 & \\
\hline
\end{tabular}

Fig. 2. Synthetic indicator of the technical infrastructure development ( $\left.\mathrm{W}_{\mathrm{DIT}}\right)$.

The analysis concerning the length of infrastructural networks and the number of individual connections shows that development is rather proportional. The exceptions are two groups of cities:

- the units with a visible increase of the length of the technical infrastructure with no corresponding increase in the number of connections - these include cities such as: Koszalin, Jelenia Góra, Tarnobrzeg, all of them with negative migration balance,

- the units, where the infrastructure is not being expanded, but an increase in number of new connections to the existing infrastructure can be observed - e.g.: Leszno, with growing number of inhabitants and Ostrołęka, Skierniewice and Zamość, with a decreasing population.

The evaluation of particular types of the technical infrastructure indicates that the development of water and sewage systems was at the same level. There is a slightly greater emphasis on gas network development. All the cities invest both in the gas network expansion and in individual connections. The last conclusion is rather obvious. There is a need to make up for the delays in implementing this kind of heat source. This is also encouraged particularly by favorable conditions, such as: the large number of recipients in a spatially limited area and an increase in the ecological awareness of the cities' authorities and inhabitants. 
In conclusion, the changes in administrative status of the analyzed cities might have affected their demographic situation, which resulted in changes in the housing market and finally affected the needs in terms of the technical infrastructure development.

\section{References}

1. K. Cheba, Taksonomiczna analiza przestrzennego zróżnicowania wybranych wskaźników poziomu życia w ujęciu dynamicznym. Folia Pomeranae Universitatis Technologiae Stetinensis seria Oeconomica 285 (62), Wydawnictwo Uczelniane, Zachodniopomorski Uniwersytet Technologiczny w Szczecinie, 37-44 (2011)

2. J. Łukomska, Byłe stolice województw 10 lat po reformie, [w:] Dziemianowicz W., Szlachta J., Szmigiel-Rawska K. (red.), Subregionalne bieguny wzrostu, Uniwersytet Warszawski, Wydział Geografii i Studiów Regionalnych, Warszawa, s. 59-70, (2011)

3. A. Runge, Metodologiczne problemy badania miast średnich $w$ Polsce. Prace Geograficzne, z. 129, Instytut Geografii i Gospodarki Przestrzennej UJ, Kraków. s. 83101, (2012).

4. W. Szymańska, The role of the administrative functions in the development of the city in Poland (by example of degraded towns), [w:] Szymańska W. (red.), Regional Development and Public Administration in the Context of General Tendencies of XXI century, Publishing House ADNDU, Słupsk-Kharkiw, s. 5-18, (2015)

5. J. W. Komorowski, Miasta wojewódzkie a miasta postwojewódzkie w Polsce zróżnicowanie i zmiany poziomu gospodarczego w pierwszej dekadzie XXI wieku, Studia Miejskie, Uniwersytet Opolski. Opole. nr 8, s. 9-23, (2012)

6. A. Kurniewicz, P. Swianiewicz, Ból fantomowy czy realna strata? Wplyw utraty statusu stolicy województwa na rozwój gospodarczy $i$ miejsce $w$ hierarchii systemu osadniczego, Prace i Studia Geograficzne, Wydział Geografii i Studiów Regionalnych Uniwersytetu Warszawskiego.Warszawa, t. 61, nr 2, s. 25-50, (2016)

7. W. Kisiała, Wptyw utraty statusu ośrodka wojewódzkiego na rozwój miast, Prace naukowe Uniwersytetu Ekonomicznego we Wrocławiu Gospodarka lokalna i regionalna w teorii i praktyce, nr 477, Opole, s. 117-125, (2017)

8. A. Dembicka-Niemiec, Zrównoważony rozwój a funkcje miast. Badanie zwiąków między zrównoważonym rozwojem średnich miast $w$ Polsce a ewolucja ich struktury funkcjonalnej, Uniwersytet Opolski, Studia i Monografie Nr 540, Opole, (2017)

9. Local Data Bank https://bdl.stat.gov.pl/BDL/start

10. J. Runge, Metody badań w geografii społeczno-ekonomicznej-elementy metodologii, wybrane narzędzia badawcze, Wydawnictwo Uniwersytetu Śląskiego, Katowice, s. 314 (2007)

11. M.P. 2012 poz. 252, Uchwała Nr 239 Rady Ministrów z dnia 13 grudnia 2011 r. w sprawie przyjęcia Koncepcji Przestrzennego Zagospodarowania Kraju 2030 